\title{
Additions and changes to Ficus (Moraceae) in New Guinea with comments on the world's largest fig
}

\author{
Z. Ezedin ${ }^{1}$ and G.D. Weiblen ${ }^{2}$ \\ ${ }^{1}$ Department of Plant and Microbial Biology, University of Minnesota, \\ 140 Gortner Laboratory, 1479 Gortner Avenue, \\ Saint Paul, Minnesota 55108, USA \\ ${ }^{2}$ Bell Museum of Natural History, 2088 Larpenteur Ave West, \\ St Paul, MN 55113, USA \\ gweiblen@umn.edu
}

\begin{abstract}
Two new species of Ficus in New Guinea are described and a third species is resurrected to improve the classification of Ficus sect. Dammaropsis, sect. Sycidium, and sect. Papuasyce. Ficus sect. Dammaropsis is extraordinary in producing by far the world's largest known figs. New morphological, ecological, and molecular observations support recognising as separate species the lowland and highland forms of Ficus dammaropsis (Warb.) Diels sensu lato. The lowland form, described here as Ficus brusii Weiblen, is distinguished from the highland form by its much smaller figs that bear recurved, acuminate lateral bracts. The description of Ficus dammaropsis is amended to refer to the highland form with the world's largest fig and includes $F$. dammaropsis var. obtusa Corner. Evidence from DNA suggests pollination by distinct fig wasp species and reproductive isolation between Ficus brusii and F. dammaropsis. Ficus hystricicarpa Warb. (sect. Sycidium) is resurrected from synonymy under Ficus wassa Roxb. on account of its conspicuously warty and hispidulous syconia. Lastly, an ecological genetic study led to the discovery of a third species occupying an altitudinal contact zone between Ficus itoana Diels of hill forest and Ficus microdictya Diels of montane forest. These members of the New Guinea endemic Ficus sect. Papuasyce point to a rare evolutionary shift in the sexual system from functional dioecy to monoecy. Here we describe Ficus umbrae Ezedin \& Weiblen on the basis of morphological intermediacy and molecular evidence to report the first functionally gynomonoecious Ficus species.
\end{abstract}

Keywords. Coevolution, gynodioecious, gynomonoecy, Papua, speciation.

\section{Introduction}

The cosmopolitan genus Ficus L. (Moraceae) is one of the largest genera of angiosperms with over 870 species described to date (POWO, 2019). It is the largest member of the Moraceae and is best known for its unique obligate mutualism with pollinating fig wasps (Hymenoptera: Chalcidoidea: Agaonidae). Coevolutionary dynamics between figs and fig wasps are estimated to have spanned at least the past 75 million years (Cruaud et al., 2012). The myriad of Ficus species span the breadth of all woody plant forms including trees, shrubs, climbers, epiphytes, and hemi-epiphytes (Berg \& Corner, 2005). Despite its extraordinary ecological diversity, the genus is highly recognisable in the field due to ubiquitous features including conical stipules, copious white latex, and the unmistakable fig (syconium), an inflorescence comprised of small 
unisexual flowers lining the inner wall of an enclosed receptacle that is tightly sealed by apical bracts. Recognising the monophyly of the genus despite its remarkable evolutionary expansion and diversification across the world, Corner (1958) stated that if it were not for other Moraceae, Ficus would be treated as a family in its own right.

New Guinea has long been considered to be an important centre of diversification for the genus with 157 species or nearly $20 \%$ of the global total (Corner, 1958; Rønsted et al., 2008; Whitfeld \& Weiblen, 2010). Unlike other diverse genera found throughout the island, the diversification of Ficus in New Guinea is thought not only to have been driven by the active orogeny of the island during the past 40 million years but also by the specialised pollination system where the evolution of host preferences in figs wasps can lead to rapid speciation (Moe et al., 2012; Weiblen, 2006). Figs comprise an integral part of New Guinea forests as they are not only among the most commonly encountered forest plants, but also serve as an ecologically important source of food for native wildlife (Shanahan et al., 2001). They are widespread in the lowlands, especially in disturbed forests. Numbers of species are highest in the lowlands and forests up to $900 \mathrm{~m}$, although there are many montane species some of which reach elevations up to $2800 \mathrm{~m}$. Local taxonomic diversity and the sheer abundance of the genus can be remarkable. For example, Ficus alone comprises some 15\% of nearly 300,000 stems above $1 \mathrm{~cm}$ in diameter at the Wanang 50 ha forest dynamics plot in Madang Province, Papua New Guinea (Vincent et al., 2018). Furthermore, with 37 species known from the Wanang plot, New Guinea forests appear to rival many other tropical forest plots in numbers of fig species. It is perhaps not surprising that ecological and genetic studies in New Guinea continue to uncover new taxa in this active centre of diversification. Here we treat two new endemic species and a third is resurrected to improve the classification of New Guinea Ficus, increasing to 160 the total number of species known from the island.

\section{Methods}

Ecological genetic research (Souto-Vilarós et al., 2018), recent collecting, and field observations made by the authors and colleagues in New Guinea have led to the recognition of new species and necessitate the taxonomic changes described below. Morphological measurements were performed either manually at the MIN herbarium or digitally using high-resolution images and ImageJ software (Schneider et al., 2012) in the case of material from other herbaria. Measurements and characteristics are for dried specimens unless otherwise noted. Taxonomic descriptions are formatted to mirror those of the Flora Malesiana for ease of comparison with Berg \& Corner (2005) and to assist in highlighting newly recognised features that distinguish taxa.

Geographic distributions for Ficus dammaropsis and F. brusii were inferred from coordinate data and locality descriptions of herbarium specimen labels (Fig.1). For specimens without coordinates, localities were estimated based on the verbatim locality data given on the herbarium label using web tools such as GoogleEarth and GeoLocate. 


\section{Taxonomic Treatment}

1. Ficus dammaropsis Diels, Bot. Jahrb, Syst. 67: 205 (1935). - Dammaropsis kingiana Warb., Bot. Jahrb. Syst. 13: 296 (1891) [non = Ficus kingiana Hemsl. (1897)]. - TYPE: Papua New Guinea, Morobe Prov., Sattelberg, c. $850 \mathrm{~m}$ asl, (no date), O. Warburg 20580 (lectotype B [B 10 0294149]; isolectotypes B [B 100294147 \& 10 0294148]). (Fig. 2 \& 3)

Ficus dammaropsis Diels var. obtusa Corner, Gard. Bull. Sing. 18: 42 (1960); Berg \& Corner, Fl. Males. Ser. I, vol. 17: 377 (2005). - TYPE: Papua New Guinea, Northern Prov., Yodda River, $1300 \mathrm{~m}$ asl, 21 December 1935, C.E. Carr 13942 (holotype BM; isotypes CANB, L (n.v.), SING).

Small, sparsely branched pachycaul tree up to $10 \mathrm{~m}$ tall, latex white and copious. Twigs 10-30 mm thick, terete to subterete, white puberulous to subglabrous, with hollow cavities; periderm flaking off. Leaves spirally arranged, elliptic to sub-ovate, 32-75 × 23-60 cm, (sub)coriaceous, brittle when dry, apex apiculate to cuspidate, base cordate, margins strongly crenate to sublobate; adaxial surface glabrous to hispidulous or \pm scabrous, rarely smooth; abaxial surface white puberulous to hirtellous to subtomentose or \pm scabrous; cystoliths present beneath; secondary veins 7-11 pairs, basal pair branched, tertiary veins scalariform; waxy glands often present in axils or furcations of the lateral veins; petiole $(2-) 4-9(-20) \mathrm{cm}$ long, glabrous, white puberulous to hispidulous to sub-strigose, the epidermis sometimes flaking off; stipules 10-30 cm long, white hirtellous to substrigose to sericeous, caducous or subpersistent on fig-bearing nodes. Figs axillary, cauliflorous, solitary or paired, subsessile or with peduncle up to $1 \mathrm{~cm}$ long, basal bracts often indistinct, passing into the lateral bracts, when distinct up to $5.3 \mathrm{~cm}$ long; receptacle ovoid to ellipsoid, 5-9 $\times$ $3.5-6 \mathrm{~cm}$ when dry and up to $22 \times 18 \mathrm{~cm}$ when fresh, walls up to $1 \mathrm{~cm}$ thick when dry and with noticeable rumination of the central cavity, internal hairs absent, covered in numerous obtuse bracts, apex \pm convex, at maturity deep red to dark purple (seed figs) or remaining greenish (gall figs); lateral bracts 1-4×4-6 cm, subcircular and rounded to broadly ovate and subacute, imbricate, appressed but often slightly raised upon maturity; ostiole 1-1.5 cm in diam. when dry, surrounded by suberect apical bracts; galls $2.5 \times 1.9 \mathrm{~mm}$.

Distribution. Highland New Guinea - Papua, Indonesia and Papua New Guinea (Fig. 1).

Habitat and ecology. In montane forests from (850-)1200-2600 m elevation, often found in secondary forests and abandoned garden plots. Non-pollinating wasps (Tenka percaudata Boucek) associated with this species have been observed with extremely long ovipositors measured at up to $24 \mathrm{~mm}$ in length, among the longest of all fig wasps. This adaptation appears to be associated with parasitising the galls of the pollinator, Ceratosolen abnormis sensu lato by piercing the unusually thick syconium, 


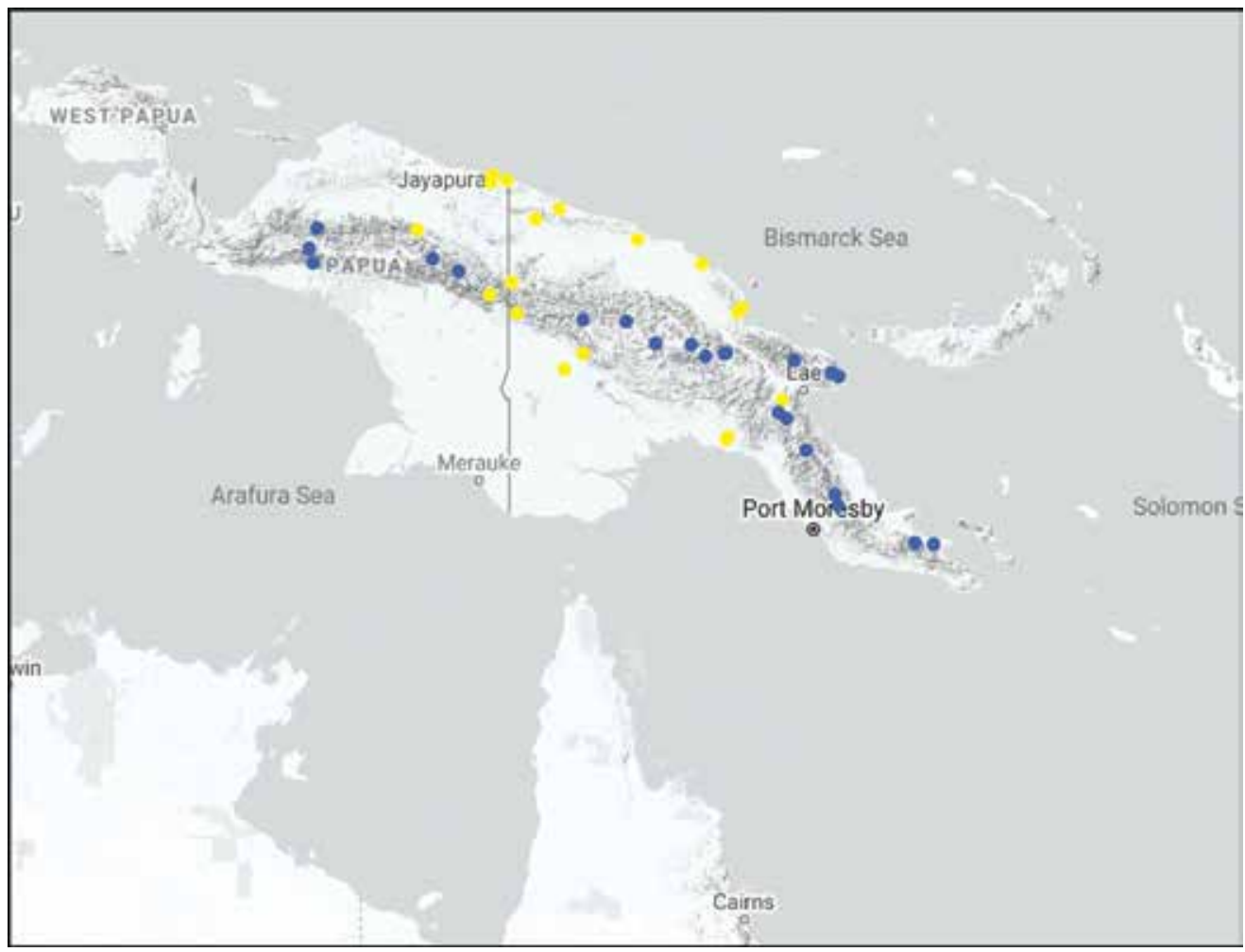

Fig. 1. Distribution map illustrating the altitudinal separation of Ficus brusii and F. dammaropsis. The lowland species, Ficus brusii, (yellow) is commonly found below $900 \mathrm{~m}$ asl whereas $F$. dammaropsis (blue) is commonly encountered above $1200 \mathrm{~m}$.

among the thickest-walled of all figs. Although seed dispersal mechanisms have been recorded for Ficus dammaropsis sensu lato, it is not entirely known to which form they belong. For a list of all observed animal feeders of Ficus dammaropsis sensu lato, see the entry under F. brusii below. One collection (Streimann NGF 21089) notes "end branches hollow, with ants" suggesting potential myrmecophily and yet ants are known predators of pollinating fig wasps (Weiblen et. al., 2001).

Local names and uses. Openha (Dunantina: Wagama), Emmi (Chimbu: Masul), Minimp (Minj: Wahgi), Minimbi (Tomba: Bo-Ung), Upit (Yawan: Yau), Kolep (Amung: Kal).

The young leaves are cooked as vegetable greens and eaten, often with starchy tubers or meat. Leaves used to cover food when cooking with earth ovens. Cultivated or otherwise selectively retained at the interface of garden plots and regenerating forests throughout highland New Guinea.

Etymology. Named by Otto Warburg in reference to the striking similarity of the syconia to the cones of Agathis dammara (Lamb.) Poir, which is in turn named after the Malay word for resin. 

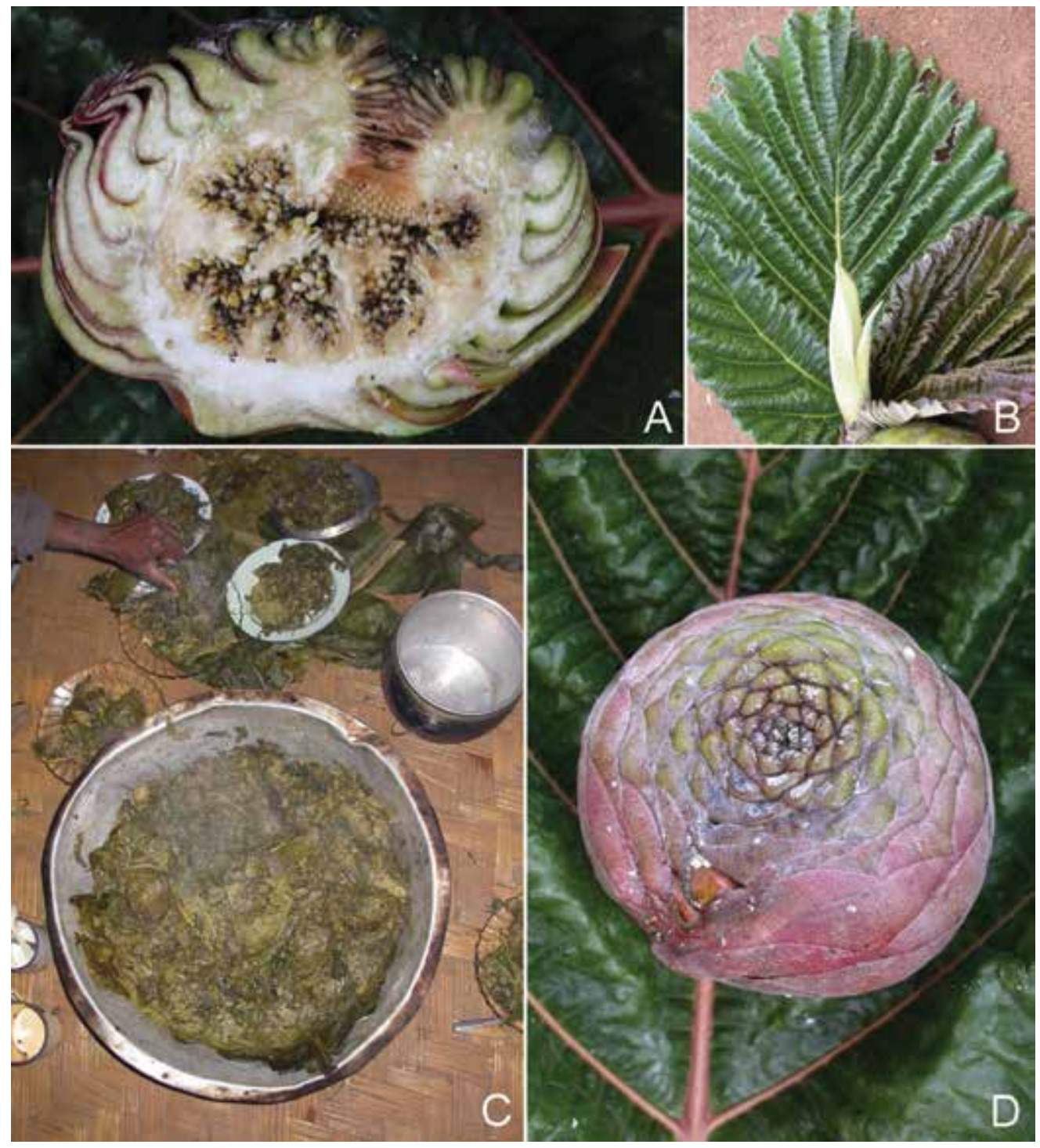

Fig. 2. Ficus dammaropsis Diels. A. Longitudinal cross section of a gall fig showing ostiolar bracts, lateral bracts and ruminate receptacle bearing short-styled pistillate florets in the central cavity and ostiolar staminate florets in bud. B. Pleated leaves and stipules enclosing the shoot apex. C. Freshly stewed leaves served during a meal at Mu Village, Chimbu Province, PNG. D. Syconium post-pollination exhibiting obtuse lateral bracts. A from Weiblen 2956. B-D from Weiblen 2142. [See species description for dimensions.] (Photos: A, R. Montgomery; B-D, G. Weiblen). 


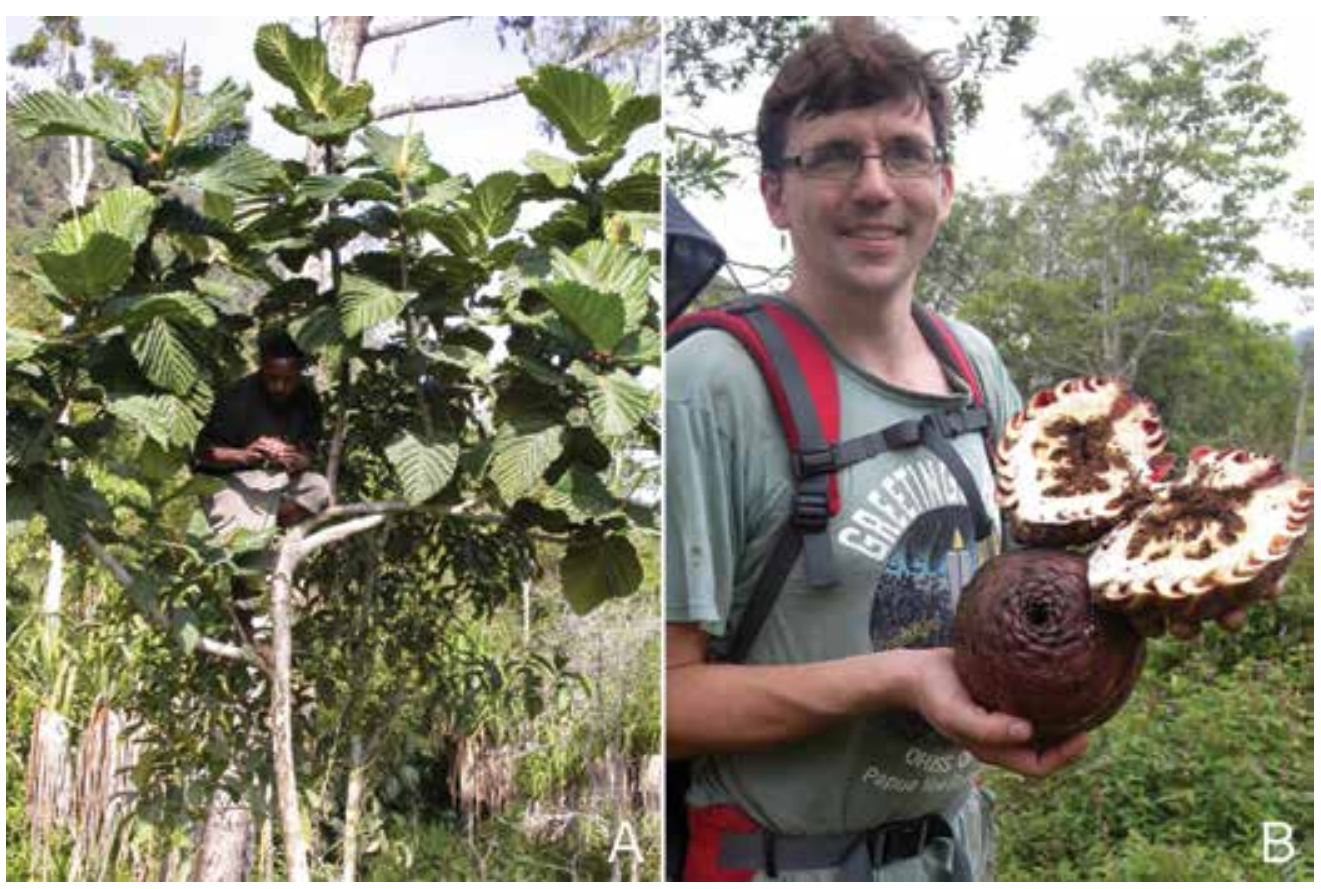

Fig. 3. Ficus dammaropsis Diels. A. Habit of a mature tree at Mu Village, Chimbu Province, PNG. B. The senior author with large, mature syconia at Yawan, Morobe Province, PNG. A from Weiblen 2142. [See species description for dimensions.] (Photos: A, G. Weiblen).

Additional specimens examined. INDONESIA. Papua Province: Jaba Hoea, Mt. Jaya area, PT-Freeport Indonesia Concession, 1400 m asl, 24 May 2005, Cook 184 (K, L); Bergwald im Memektal nordlich von Talim, 1600 m asl, 18 Mar 1976, Hiepko \& Schultze-Motel 1472 (L); Jayawaijaya Distr., Angguruk Area, 1400 m asl, 12 Jun 1975, Sinke 75 (L).

PAPUA NEW GUINEA. Chimbu Province: Mu Village, near Kundiawa, $1700 \mathrm{~m}$ asl, 14 Oct 2004, Weiblen GW2142 (MIN). Eastern Highlands Province: On the road to Mt. GahavisukaPark, N of Goroka, 2100-2300 m asl, 14 Sep 1988, Baltisberger, Erdelmeier \& Rali 11811 (L); Aujura, $1800 \mathrm{~m}$ asl, Oct 1944, NGF 1113 (L). Milne Bay Province: Bank of a stream in forest, N slopes of Mt. Dayman, Maneua Range, 1370 m asl, 1 Jul 1953, Brass 23340 (L); Above Kabebe, nr. Mt. Otto, 21 Jun 1955, Gressitt 2310 (BISH); Raba Raba Subdist., Mayu 2, Mt. Suckling complex, 1745 m asl, 9 Jun 1972, LAE 54998 (L). Morobe Province: Yunzaing, $1300 \mathrm{~m}$ asl, 8 Aug 1936, Clemens 3816 (L); Bubuu Valley, vicinity of Bedei (Camp 1), 1844 m asl, 17 Feb 2012, Matoi SAJ0416 (BISH, LAE, MIN); Wau Subprovince, Manki Divide, Bulolo, $1000 \mathrm{~m}$ asl, 26 Jul 1979, LAE 74472 (L); Below Manki trig, Bulolo, ca. $1600 \mathrm{~m}$ asl, 16 Apr 1965, NGF 21089 (BISH); Yawan Village, $1721 \mathrm{~m}$ asl, 26 Aug 2010, Weiblen YS4F0403 (LAE, MIN). Oro Province. Lala River, ca. 1500 m asl, 26 Dec 1935, Carr 14026 (BISH, L). Western Highlands Province: Terreman, on N bank of Lai River, 1.5 miles WNW of Wabag, 1.5 miles from S.D.A. Mission, $2000 \mathrm{~m}$ asl, 24 Jul 1964, Flenley ANU2054 (A, K, L, LAE); Between Dona and Nondugl, temporary village on sing-sing grounds, ca. $1700 \mathrm{~m}$ asl, 17 Sep 1960, Fosberg 41210 (BISH); Near Tomba village, S slope of Mt. Hagen Range, 2550 $\mathrm{m}$ asl, 5 Sep 1956, Hoogland 6138 (L, US); 10 miles from Kopiago on Koroba Road, Kopiago Subdistr., 1700 m asl, 4 Nov 1968, NGF 37347 (A, BOG, BRI, CANB, K, L, SING). 
Notes. Placed in Ficus subg. Sycomorus sect. Dammaropsis, this species is most notable for its large figs - the largest of any in the world. Delimiting the species has remained problematic ever since Corner (1960) described Ficus dammaropsis var. obtusa from collections above $1000 \mathrm{~m}$. Two forms have been informally recognised in the field as 'highland' and 'lowland' Ficus dammaropsis. Populations are not continuous across the landscape and no contact zone between the two has been observed. We assumed that the type of Dammaropsis kingiana Warb., collected at $850 \mathrm{~m}$ asl (Warburg 20580), represented the lowland form but, despite being collected at a relatively low elevation, it clearly retains the highland features of strongly pleated leaves, sublobate margins, and obtuse, semicircular bracts on the syconia. Corner's incomplete attempt to recognise two forms might be attributed to the limited number of collections available in 1960 . Later, after personally observing Ficus dammaropsis in New Guinea, he wrote "the species clearly calls for further investigation of living plants to ascertain both variation and wild occurrence" (Corner, 1978). With recent collections and field observations of both forms, two species can now be accurately separated. Here, we sink Ficus dammaropsis var. obtusa into synonymy with the type variety and the lowland form is newly described as Ficus brusii.

\section{Ficus brusii Weiblen, sp. nov.}

Similar to Ficus dammaropsis, but differing by laminas that are smooth and weakly pleated when fully expanded and with smaller syconia bearing recurved, acute to acuminate lateral bracts. - TYPE: Papua New Guinea, Sandaun Prov., Near the Remo River, Utai, $300 \mathrm{~m}$ asl, 14 November 2003, G.D. Weiblen GW2059 (holotype LAE; isotypes MIN, A, US). (Fig. 4 \& 5)

Small, sparsely branched pachycaul tree to $13 \mathrm{~m}$ tall, latex white and copious. Twigs 7-28 mm thick, terete to subterete, subglabrous or sparingly hispidulous, with hollow cavities; periderm flaking off. Leaves spirally arranged, elliptic to sub-ovate, 40-80 $\times$ 30-65 cm, (sub)coriaceous to subchartaceous, brittle when dry, apex apiculate to cuspidate, base cordate, margins subentire to crenate; adaxial surface glabrous, smooth or rarely \pm scabrous, abaxial surface glabrous to sparingly hispidulous; cystoliths present beneath; secondary veins 8-12 pairs, basal pair branched, tertiary veins scalariform; waxy glands often present in axils or furcations of the lateral veins; petiole (2-)4-17(-23) cm long, often glabrous, rarely white puberulous to hispidulous, the epidermis often flaking off when glabrous; stipules 10-25 cm long, glabrous to white hirtellous, caducous or subpersistent on fig-bearing nodes. Figs axillary or cauliflorous, often solitary, subsessile or with peduncle up to $1.2 \mathrm{~cm}$ long, basal bracts often distinct and up to $3.6 \mathrm{~cm}$ long; receptacle subglobose to ovoid, 2.9-6 $\times 3.2-4.2$ cm when dry and $6.5-8.5 \times 4.5-8 \mathrm{~cm}$ when fresh, walls up to $0.7 \mathrm{~cm}$ thick when dry, with or without small projections into the central cavity, internal hairs absent, covered in numerous bracts completely obscuring syconium wall (rarely with syconium wall partially visible), apex \pm convex, at maturity golden yellow brown to orangish brown to reddish brown, often with yellow-green longitudinal streaks; lateral bracts $1.5-4 \times$ 
1.2-4 cm, (sub)acute to strongly acuminate, tips reflexed, often helicoid, fully erect upon maturity, never appressed; ostiole 3-8 $\mathrm{mm}$ in diam. when dry, surrounded by usually erect, non-recurving bracts; galls $1.7-2.1 \times 1.4-1.7 \mathrm{~mm}$; seeds $1.2-1.6 \times 0.7-$ $0.9 \mathrm{~mm}$.

Distribution. Lowland New Guinea - Papua, Indonesia and Papua New Guinea (Fig. $1)$.

Habitat and ecology. In lowland forests, up to 900(-1500) m elevation, often found along streams and rivers. Common in secondary forest, degraded areas, and in garden plots. DNA barcodes from Ceratosolen abnormis, the pollinator of Ficus dammaropsis sensu lato, indicate that there is sufficient genetic divergence between lowland and highland pollinator populations to recognise them as separate fig wasp species (Moe \& Weiblen, 2010). The holotype and several paratypes of the pollinator were reared from lowland Ficus dammaropsis sensu lato (Wiebes, 1963), suggesting that the pollinator of $F$. brusii should be regarded as Ceratosolen abnormis while the pollinator of $F$. dammaropsis sensu stricto awaits description. The ostiolar pore of gall figs opens to $0.5-1 \mathrm{~cm}$ wide as pollen-bearing female fig wasps exit the syconia and ants infest the interior to prey on escaping females and flightless males.

Most frugivores bite or remove figs from plants but some of the small birds and bats attracted to Ficus brusii lap up the gelatinous contents of mature seed figs as they are extruded through the ostiolar pore (Weiblen et al., 2010). This unusual seed dispersal mechanism among figs was first observed among honeyeaters (Meliphaga spp.) at lower elevations of Crater Mountain, PNG (Mack \& Wright, 1996). Mammal species recorded feeding on the figs of Ficus dammaropsis sensu lato include: Rufous Spiny Bandicoot (Echymipera rufescens), Spiny Bandicoot (Echymipera kalubu), Raffray's Bandicoot (Peroryctes raffrayanus), Grey Cuscus (Phalanger orientalis), Silky Cuscus (Phalanger vestitus), Spotted Cuscus (Spilocuscus maculatus), Greater Naked-backed Bat (Dobsonia mollucense), Common Long-tongued Fruit Bat (Macroglossus minimus), Broad-striped Tube-nosed Bat (Nyctimene aello), Common Tube-nosed Bat (Nyctimene albiventer), Lesser Tube-nosed Bat (Paranyctimene raptor), Geoffroy's Rousette (Rousettus amplexicaudatus), and the Common Blossom Bat (Syconycteris australis) (Shanahan et al., 2001).

Local names and uses. Alaf (Ohu: Amele), Bacan (Nobanob: Amron), Gangan (Baitabag: Amron), Hokomun (Salemben: Amben), Pindo (Wolwale: Northern One), Magsuoh (Utai: Fas), Rokquam (Wamangu: Urimo).

Leaves used as plates to serve food, to wrap food, or to cook food in earthen ovens.

Etymology. Named in honour of Brus Isua of Ohu Village, Amele District, Madang Province. A field botanist and founding member of the New Guinea Binatang Research Centre, Mr Isua first assisted the senior author with $\mathrm{PhD}$ dissertation fieldwork during 1995-1997. Lacking formal education, Isua is a parataxonomist and discovered the first palaeotropical braconid wasp associated with figs, Ficobracon brusi (Van 

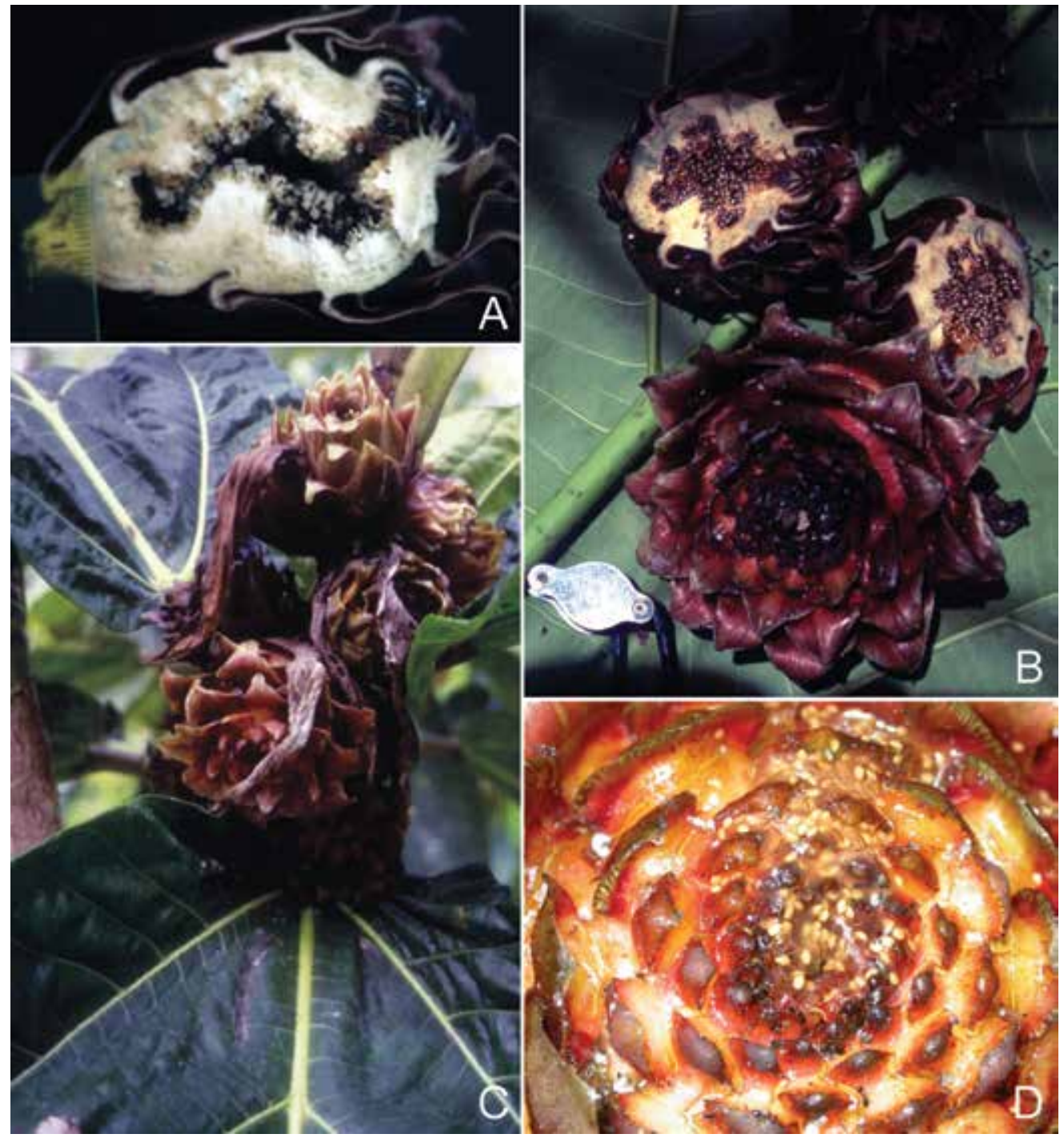

Fig. 4. Ficus brusii Weiblen. A. Lateral cross-section of a pre-receptive gall fig bearing sparse lateral bracts. B. Lateral cross-section of post-pollination gall figs displaying galled pistillate florets and ostiolar staminate florets in bud. C. Pre-receptive syconia displaying acuminate, recurved lateral bracts (A). D. Mature seed fig extruding gelatinous seed-bearing mass through the ostiole. A from UlaiG050; B from Weiblen524A; C from IsuaB186; D from Weiblen \& Dumont 1744. [See species description for dimensions.] (Photos: G. Weiblen).

Achterberg \& Weiblen, 2000). He developed the "bush laboratory" concept in 1998 where local landowners build and operate village-based field stations. The model has been successfully deployed in ecological research throughout Papua New Guinea. It demonstrates the advantage of long-term observations and collecting that is beyond the reach of foreign students and expert investigators who can participate in fieldwork 
or supervise only periodically. He is a co-author of at least seven peer-reviewed publications (e.g. Novotny et al., 2007) and is acknowledged for his contributions in scores of others.

Additional specimens examined. INDONESIA. Papua Province: Hollandia and vicinity, c. 5 $\mathrm{m}$ asl, Jun 1938, Brass 8892 (L); 6 km SW of Bernhard Camp, Idenburg River, $1200 \mathrm{~m}$ asl, Feb 1939, Brass 12964 (L); Albatros biv., forest, 30 m asl, May 1926, Docters van Leeuwen 9162 (L); Orion Mts., Tenma River, 1500 m asl, 19 May 1959, Kalkman 4086 (L); Town of Sukarnapura (Hollandia), 200 m asl, 20 Jul 1966, Kostermans \& Soegang 13 (L); Weg naar Hollandia-Binnen, c. 5 m asl, 19 Sep 1956, Versteegh BW3933 (L); Sekoli-vlakte, O.A. Hollandia, c. 75 m asl, 15 Feb 1960, Versteegh BW7534 (L).

PAPUA NEW GUINEA. East Sepik Province: Near Wamangu Village, $100 \mathrm{~m}$ asl, 19 Oct 2004, Weiblen, Isua \& Andreas 2195 (LAE, MIN). Gulf Province: Lohiki Village area, junction of Lohiki and Vailala rivers, $20 \mathrm{~m}$ asl, 24 Jan 1966, Schodde \& Craven 4281 (L); Kerema Subprovince, Near Lohike village, Vilala River, 25 m asl, 26 Jun 1980, LAE 72490 (L). Madang Province: Ohu Village, 2 Aug 1994, Basset s.n. (BISH); W of Madang, Kau Wildlife Area (Baitabag Village), 100 m asl, 24 Feb 1999, Gardner 9208 (AK); Kau Wildlife Area, Baitabag Village near Madang, 50 m asl, 24 June 1995, Weiblen 524A (MIN); Ohu Conservation Area, Ohu Village nr. Gum River, 100 m asl, 17 Jun 1996, Weiblen \& Isua B110 (L); Kau Wildlife Area, Baitabag village, $50 \mathrm{~m}$ asl, 29 Jan 2003, Weiblen \& Dumont 1744 (MIN); Kau Wildlife Area, Baitabag village, $50 \mathrm{~m}$ asl, 30 Jan 2003, Weiblen \& Dumont 1752 (MIN); Morox Village, 60 m, 15 Feb 2005, Isua 2795 (MIN). Sandaun Province: Along Pieni River near Walwali Village, Aitape Subdistr., ca. 30 m asl, 23 Jun 1961, Darbyshire \& Hoogland 8009 (L); Yapsiei, $112 \mathrm{~m}$ asl, 26 Mar 2004, Janda Y074 (LAE, MIN); Wutung Subprovince, $10 \mathrm{~km}$ South of Wutung Patrol Post, $60 \mathrm{~m}$ asl, 4 Sep 1982, LAE 56400 (L). Western Province: Nomad Subprovince, Junction of Rentoul \& Strickland River, $80 \mathrm{~m}$ asl, 11 Nov 1979, LAE 71555 (L); Near Base Camp, Kiunga Subdist., 760 m asl, 5 Nov 1969, NGF 45824 (L, BRI, CANB, A); Baia River survey track C along Tikawe Creek, 290 m asl, 15 Feb 2008, Takeuchi, Gambia \& Jisaka 22976 (L).

Notes. This species had long been informally recognised as the lowland form of Ficus dammaropsis sensu lato and included by Corner in Ficus dammaropsis var. dammaropsis. It is clearly distinct from the highland form by its weakly pleated leaves when fully expanded, smaller figs, and acuminate recurved lateral bracts.

Only two specimens, Brass 12964 and Kalkman 4086, were collected above $1000 \mathrm{~m}$ in elevation and are perceived to be the extreme limit of its range, as it is most commonly encountered below $500 \mathrm{~m}$. Both the latter specimens also possess lamina margins with deeper crenation and reddish venation, which appear to approach that of the highland-type Ficus dammaropsis. Johns 9148, collected at $3300 \mathrm{~m}$ among "subalpine shrubbery and grassland" represents the highest collection by far of any Ficus species in New Guinea. Initially assumed to be Ficus dammaropsis, examination of figs preserved in spirit refer the specimen to F. brusii. Johns' collections around Freeport (Papua, Indonesia) were made along an elevational transect from sea level to $3300 \mathrm{~m}$. If the label locality is not erroneous, cultivation might account for the presence of the lowland species in such an extreme location. 

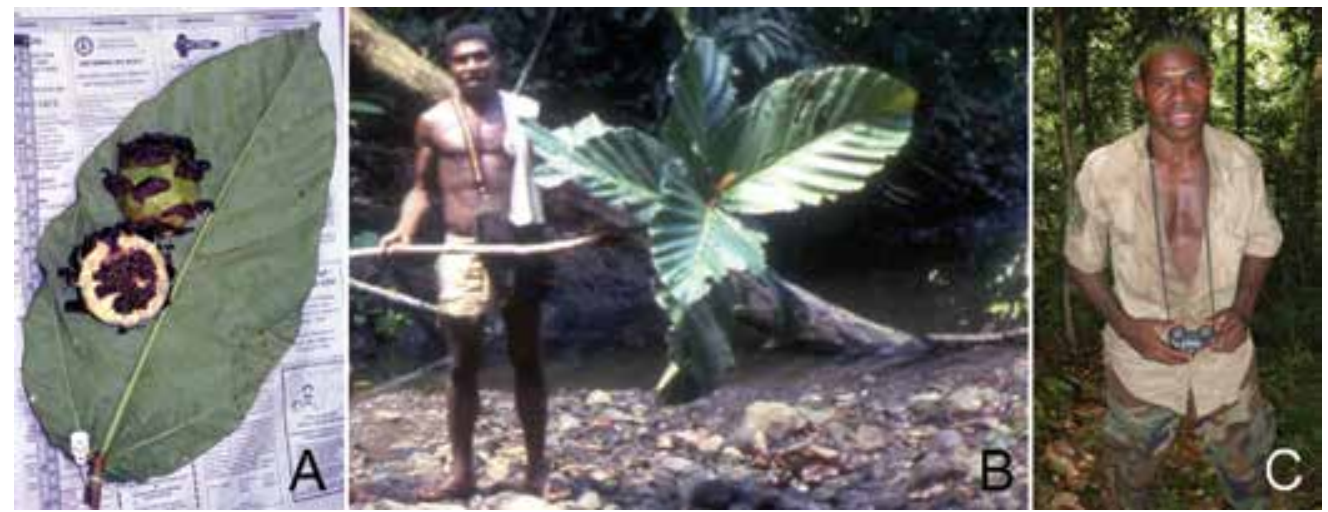

Fig. 5. Ficus brusii Weiblen. A. Lamina and syconium bearing fewer lateral bracts than $F$. dammaropsis. B. Branch displaying shallowly pleated leaves compared to $F$. dammaropsis (WIAD Conservation Area, Ohu, Madang). C. Brus Isua in 2002 at Yuat River, East Sepik Province, PNG. A from IsuaB110. [See species description for dimensions.] (Photos: G. Weiblen).

Corner noted the specimens of Kostermans \& Soegang 13 and Brownhill 1 as potentially representing a separate third variety, which he informally named Ficus dammaropsis var. parvibracteata, based on the smaller syconia. The syconia $(3 \times 3.45$ $\mathrm{cm}$ ) fall well within the limits of Ficus brusii, the smallest of which is recorded in Weiblen \& Dumont $1744(2.9 \times 3.7 \mathrm{~cm})$; moreover, they share other characters that justify placement under this species such as acuminate bracts, glabrous abaxial lamina, and weakly pleated leaves.

3. Ficus hystricicarpa Warb. in Schum. \& Lauterb., Nachtr. Fl. Schutzgeb. Südsee 244 (1905). - TYPE: British New Guinea [Papua New Guinea], [no locality, no date], H.O. Forbes s.n. (holotype B [B 10 0279265]). (Fig. 6)

Small tree to $8 \mathrm{~m}$ tall, latex white. Twigs 3-4 mm thick, glabrous to sparsely hispidulous, periderm often flaking when dry; internodes mostly hollow. Leaves spirally arranged; lamina oblong to elliptic to subobvate, $12-25 \times 5-9 \mathrm{~cm}$, symmetric to slightly asymmetric, membranous to (sub)coriaceous, base cuneate to obtuse, margin entire to coarsely crenate to dentate, often lobate when juvenile or with basal lobes at maturity, \pm revolute; adaxial surface dark green, abaxial surface light green, cystoliths on both sides, lower surface drying darker than above or \pm similar; secondary veins (4-)6-9 pairs, the basal pair running close to margin, up to $1 / 3$ the length of the lamina, mostly unbranched, tertiary venation scalariform to reticulate; waxy glands at axils of lateral veins; petiole $0.8-2.5(-4) \mathrm{cm}$ long, varying lengths on the same twig, glabrous to sparsely white hispidulous, epidermis often flaking off; stipules subulate, stiff and \pm keeled, often finely striate, $0.3-1 \mathrm{~cm}$ long, glabrous to sparsely appressed 


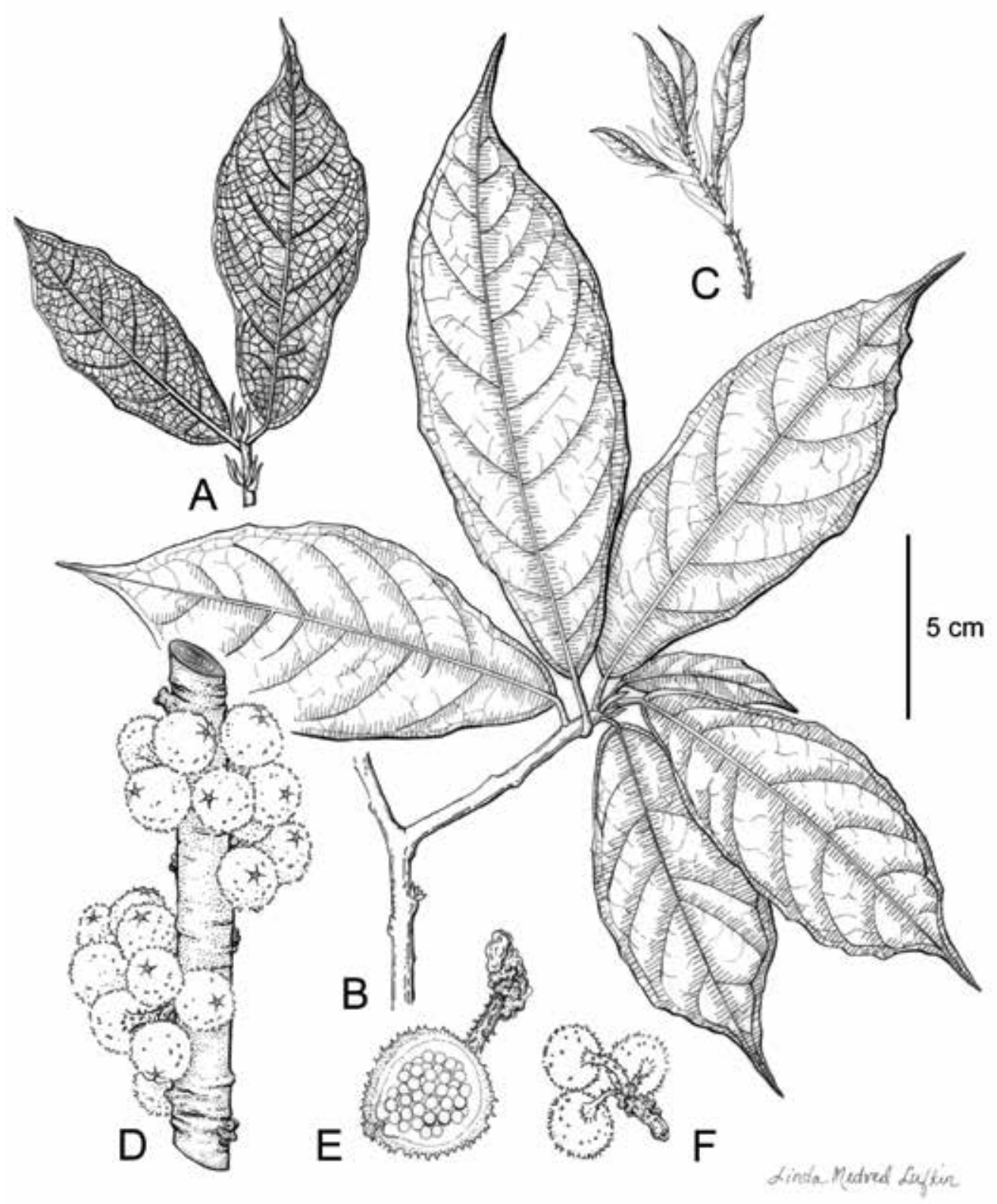

Fig. 6. Ficus hystricicarpa Warb. A. Shoot apex displaying abaxial leaf surfaces. B. Branch displaying adaxial surface of leaves. C. Expanding shoot apex displaying stipules and epidermal prickles. D. Cauliflorous figs on short shoots. E. Fig in lateral section displaying achenes and pointed, warty epidermal protrusions on the surface of the receptacle. $2 \times$ scale. F. Pedunculate figs. From $B A G-049$. 
puberulous, early caducous to (sub)persistent. Figs axillary and solitary or cauliflorous along trunk, on short clusters of spurs up to $7 \mathrm{~mm}$ long; peduncle up to $1.2 \mathrm{~cm}$ long; receptacle $0.8-1.4 \times 1-1.5 \mathrm{~cm}$ when dry, covered with irregular acuminate warts, each terminating with a single hair with basal swelling, green to yellow-green at maturity, apex \pm convex; ostiole up to $0.3 \mathrm{~cm}$ in diam. when dry, usually with few erect lateral bracts, often surrounded by an overhanging rim of warty outgrowths from the syconia; internal hairs sparse and minute or absent.

Distribution. Known only from Forbes' collection and recent material from Mt. Wilhelm in Madang Province, Papua New Guinea. Forbes' reference to British New Guinea is consistent with his 1885 expeditions to the mountains of southeastern New Guinea (Van Steenis-Kruseman \& Van Steenis, 1950).

Habitat and ecology. Occurs in mid-montane forests, 1700-2700 m elevation. Unlike the bird-dispersed Ficus wassa with figs that ripen to a deep red colour and are dispersed by birds, the yellow-green colour and cauliflorous placement of figs corresponds to a fruit syndrome associated with seed dispersal by fruit bats and other mammals rather than by birds (Shanahan et al., 2001).

Local names and uses. None recorded.

Etymology. Named by Otto Warburg; derived from hystrix = 'porcupine' in Greek + carpus $=$ 'fruit' in Latin.

Additional specimens examined. PAPUA NEW GUINEA. Madang Province: Mt. Wilhelm vegetation plot 1700C, $1700 \mathrm{~m}$ asl, 2 Nov 2012, Munzinger 6897 (MPU); Bananumbu, $1700 \mathrm{~m}$ asl, 21 Jun 2013, Isua \& Legi BAG-049 (MIN); Bananumbu, $1700 \mathrm{~m}$ asl, 20 Jun 2013, Isua \& Legi BAG-045 (MIN); Kiagimanigi, 2700 m asl, 22 Feb 2013, Isua \& Legi KM 95-007 (MIN).

Notes. This member of Ficus subg. Sycidium sect. Sycidium was synonymised into Ficus wassa by Berg \& Corner (2005) as it was presumed to be an aberrant form of the latter that occurred in New Guinea. Recent field observations support the resurrection of this species on the basis of its figs with greenish colour at maturity and conspicuous, spiny warts each terminating in a single large bristle.

\section{Ficus umbrae Ezedin \& Weiblen, sp. nov.}

Similar to Ficus microdictya Diels but is distinguished by larger syconia with thicker walls, figs with pustules, and wider leaves. Also differing from other members of Ficus sect. Papuasyce (monoecious Ficus microdictya and functionally dioecious F. itoana Diels) in having trees of two sexes, one bearing figs with pistillate florets and neutered staminate florets; the other bearing figs with functional staminate florets and pistillate florets producing either seed or insect galls. - TYPE: Papua New Guinea, Madang Prov., Degenumbu, Mt. Wilhelm transect, $1700 \mathrm{~m}$ asl, 2 October 2015, Souto \& Sisol DEG-IMI-008 (holotype LAE). (Fig. 7 \& 8) 


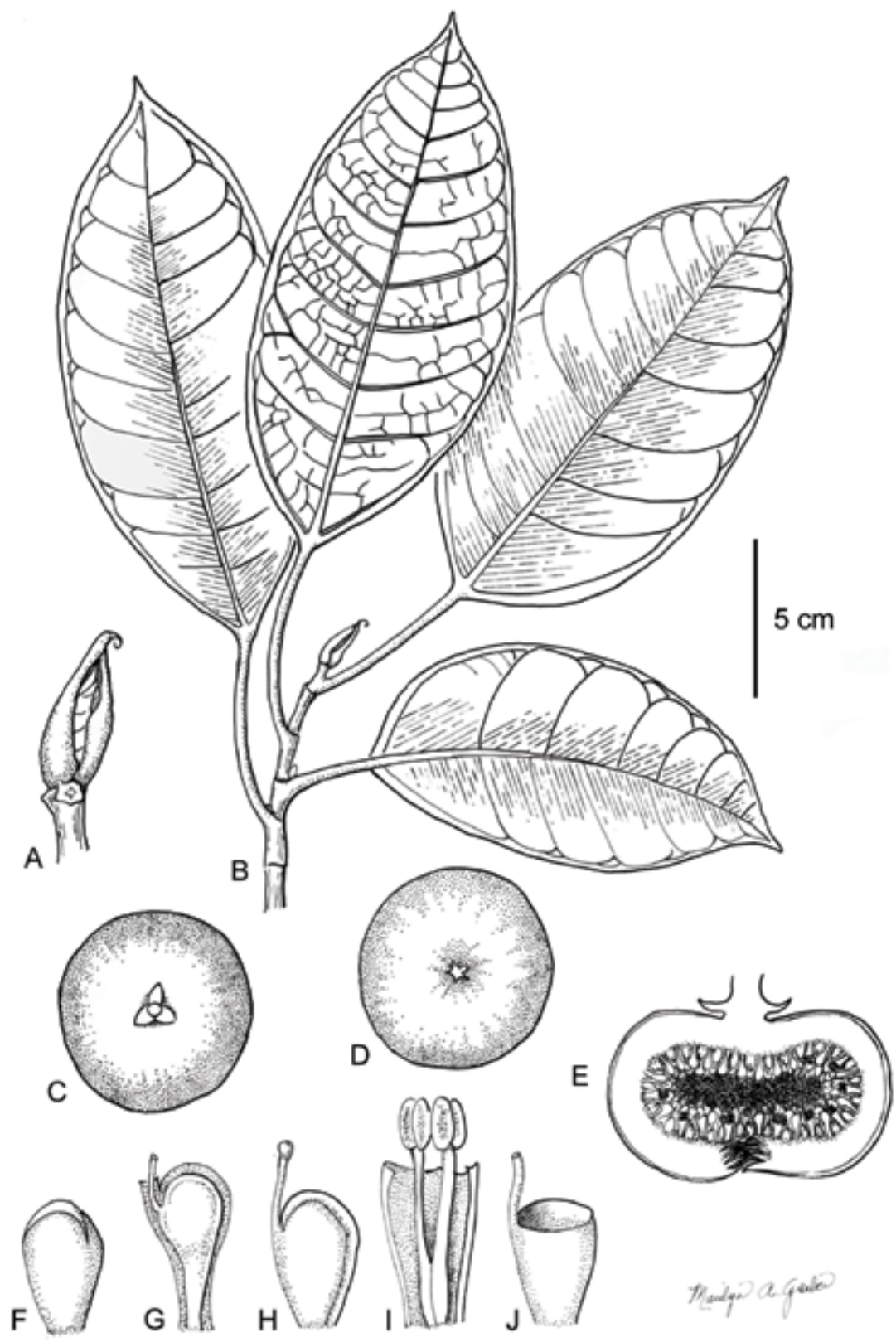

Fig. 7. Ficus umbrae Ezedin \& Weiblen with monoecious syconia. A. Terminal bud with stipules; $2 \mathrm{x}$ scale. B. Leafy branch. C. Basal view of syconium displaying three persistent basal bracts. D. Apical view of syconium displaying ostiolar bracts. E. Lateral cross-section of syconium displaying interlocking ostiolar bracts, dispersed staminate florets, and pistillate florets; $1.5 \times$ magnification. F. Achene enclosed in gamophyllous perianth. $15 \times$ scale. G. Shortstyled pedicellate pistillate floret with gamophyllous perianth. $15 \times$ scale. H. Long-styled sessile floret. $15 \times$ scale. I. Staminate floret with one of two bracts cut away. $15 \times$ scale. J. Galled pistillate floret exhibiting fig wasp exit hole. $15 \times$ scale. A-D from Souto \& Sisol DEGIMI-010; F-J from Weiblen GW421. 


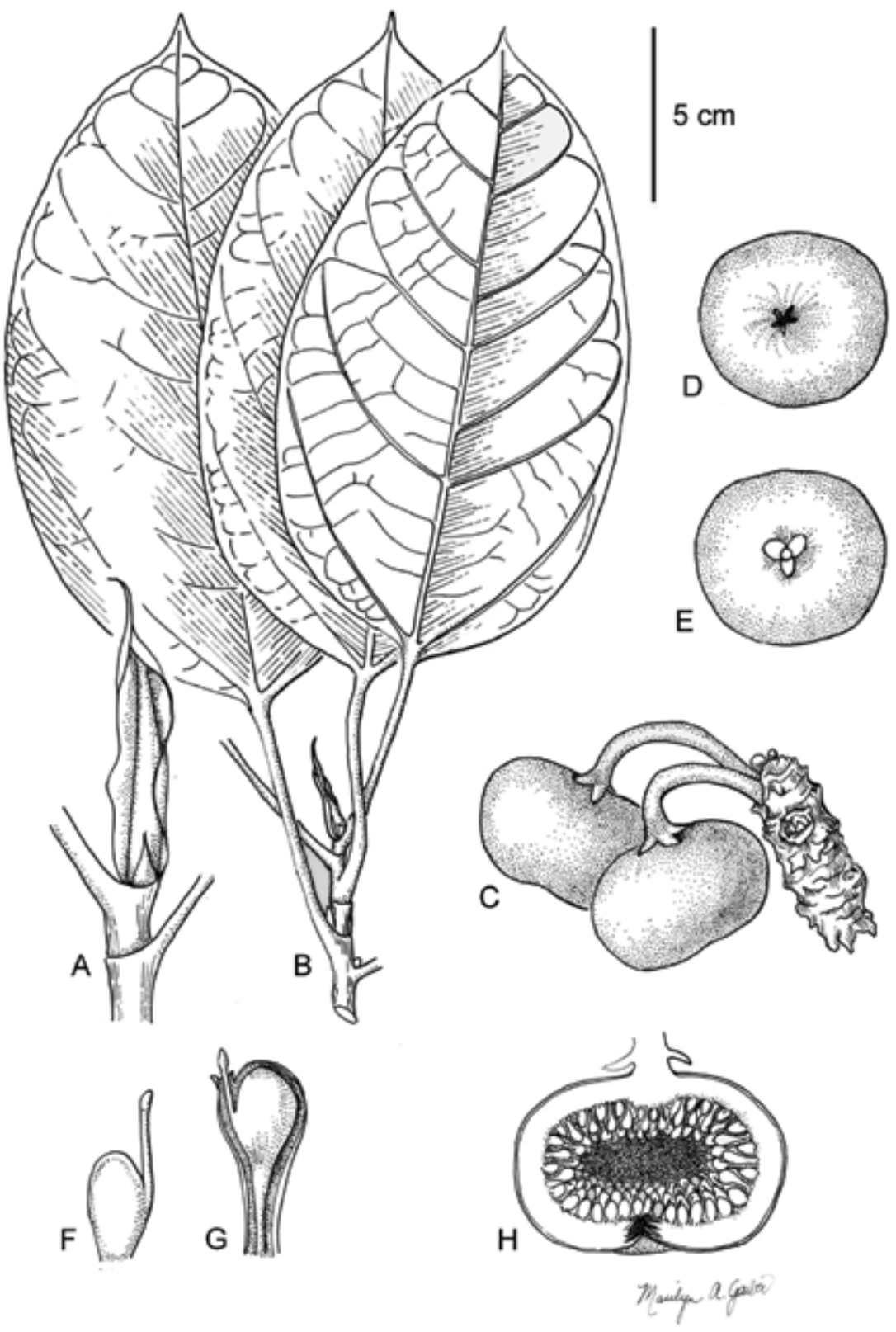

Fig. 8. Ficus umbrae Ezedin \& Weiblen with syconia bearing pistillate florets. A. Terminal bud with stipules; $3 \times$ scale. B. Leafy branch. C. Cauliflorous spur bearing syconia D. Apical view of syconium displaying ostiolar bracts. E. Basal view of syconium displaying three, persistent basal bracts. F. Long-styled sessile floret. $15 \times$ scale. G. Pedicellate, pistillate floret with gamophyllous perianth. $15 \times$ scale. H. Lateral cross-section of syconium displaying interlocking ostiolar bracts and pistillate florets. $1.5 \times$ scale. A-B from Souto \& Sisol DEGIMI-008. C-I from Weiblen GW406. 
Tree to $20 \mathrm{~m}$ tall. Twigs 3.5-5.5 mm thick, glabrous, hollow; periderm of older parts \pm flaking off. Leaves spirally arranged; lamina elliptic to oblong, $11-20 \times 6.5-11 \mathrm{~cm}$, symmetric, coriaceous, apex shortly acuminate, base subcuneate to rounded, margin entire; upper and lower surfaces glabrous and smooth; cystoliths present beneath only; lateral veins 6-10 pairs, the basal pair running \pm parallel to the margin up to $(1 / 4-$ ) 1/3 of the lamina length, unbranched, tertiary venation uniformly reticulate; paired or single waxy glands in the axils of the basal lateral veins (rarely absent); petiole 5-7.5 cm long, glabrous, the epidermis flaking off at its extremities; stipules 1.5-2.7 $\mathrm{cm}$ long, glabrous, early caducous. Figs functionally gynomonoecious, cauliflorous on clustered stout branched or unbranched leafless branchlets on trunk, often near the base); peduncle 2-3 cm long; basal bracts three, 3-4 mm long, subverticillate, coriaceous, glabrous; receptacle depressed-globose to (sub)pyriform, 2-2.8 $\times 2-3.5$ $\mathrm{cm}$ when fresh, glabrous with pustules, syconia walls $3-6.5 \mathrm{~mm}$ thick, without lateral bracts, reddish to purplish brown at maturity, apex \pm concave, ostiole $4.5 \mathrm{~mm}$ diam., \pm prominent, internal hairs absent. Seed figs bearing pistillate florets and neutered staminate florets. Gall figs bearing staminate florets and pistillate florets of two types. Pedicellate, short-styled florets with funicular stigmas are galled by Ceratosolen pollinators whereas sessile, long-styled florets with capitate stigmas set seed.

Distribution. Known from two localities, Mt. Wilhelm in New Guinea and Mt. Kavangi in New Britain.

Habitat and ecology. Occurs in mid-montane forests, around $1700 \mathrm{~m}$ elevation in mainland New Guinea and 800-1000 m in New Britain. Field observations on the mainland New Guinea suggest this species occurs in the contact zone between the lowland Ficus itoana (100-1200 m) and F. microdictya (upper montane, 1500-2000 $\mathrm{m}$ ). The figs are pollinated by an unnamed Ceratosolen species (Souto-Vilarós et al., 2018) that appears to be morphologically intermediate between the pollinator of Ficus itoana, Ceratosolen armipes Wiebes, and that of $F$. microdictya (Souto-Vilarós et al., 2018), currently known as Ceratosolen sp. "kaironkensis" nomen nudum as it too lacks formal description (Weiblen, 2004). Recent molecular evidence placed the pollinator of Ficus umbrae as sister to C. sp. "kaironkensis" (Souto-Vilarós et al., 2018).

\section{Local names and uses. None recorded.}

Etymology. From classical Latin umbra- 'shadow' or alluding to a forest spirit. The name recognises Wanamo, the dog-headed spirit or masalai regarded by the people of Degenumbu as the guardian of their forests, the type locality of this species.

Additional specimens examined. PAPUA NEW GUINEA. East New Britain: Mount Kavangi, near Malpas, Wide Bay, ca. 800 m, 10 Jun 1995, Weiblen 406 (A, LAE); Mount Kavangi, near Malpas, Wide Bay, c. 1000 m, 10 Jun 1995, Weiblen 421 (A, LAE). Madang: Degenumbu, Mt. Wilhelm transect, $1700 \mathrm{~m}$ asl, 3 Oct 2015, Souto \& Sisol DEG-IMI-010 (MIN). 
Notes. This third species of Ficus subg. Sycomorus sect. Papuasyce was initially recognised as differing from Ficus itoana and F. microdictya during fieldwork by Brus Isua along a transect from Upper Ramu to Mount Wilhelm and was thought to be a hybrid of the latter two. Bayesian admixture analysis of microsatellite genotypes from the type locality suggest that Ficus umbrae is genetically distinct from F. microdictya and $F$. itoana, albeit with some gene flow among the three (Souto-Vilarós et al., 2018). Morphologically, Ficus umbrae appears more similar to Ficus microdictya than to Ficus itoana and phylogenetic analysis resolved the former two as sister taxa with strong support (Souto-Vilarós et al., 2018). Despite its close affinity with Ficus microdictya, the volatile chemicals that attract pollinators to the figs are more similar to those of F. itoana (Souto-Vilarós et al., 2018).

These patterns suggest a possible hybridisation event in the past between Ficus microdictya and $F$. itoana in an elevational contact zone, but rather than recognise $F$. itoana $\times$ microdictya, there are several lines of evidence to support $F$. umbrae as a separate species. First, Bayesian analysis of microsatellite genotypes suggests that there are three genetically distinct lineages in sect. Papuasyce (Souto-Vilarós et al., 2018). Second, a population genetic and experimental hybridisation study of related New Guinea figs showed that distinct species can be maintained even in sympatry despite some degree of gene flow when divergent pollinator species differ in their preferences for (and performance on) different host species (Moe \& Weiblen, 2012). Lastly, each of the three Ficus species is pollinated by a morphologically and genetically distinct fig wasp species (Souto-Vilarós et al., 2018).

\section{Discussion}

This contribution to the taxonomy of New Guinea figs was inspired by David Mabberley's mentor, E.J.H. Corner. As a young student in 1992, the second author came across Corner's reprints in the library of the herbarium at Lae, Papua New Guinea. Mentors had discouraged studying New Guinea figs as "too big" and "too complex" and yet here were Corner's notes outlining clear problems in need of attention. After following in his footsteps for 27 years, it seems fitting to return to the question of Ficus dammaropsis. The largest syconia in the world fit perfectly with his Durian Theory a pachycaulous tree in the centre of diversity for the genus was obvious evidence for the origin of the fig from a multibracteate-urceolate ancestor during the post-Jurassic (Corner, 1978). Pachycaul Dammaropsis, he posited, then gave rise to the leptocaulous lines of Ficus in New Guinea and around the world. There is now plenty of evidence to conclude that he was completely wrong (Clement \& Weiblen, 2009). Or was he? In relating the New Guinea endemic Antiaropsis and New Caledonian Sparattosyce to Ficus dammaropsis on the basis of urceolate inflorescences bearing involucral bracts, it turns out that Corner (1978) had hit upon the key feature uniting Ficus with the tribe Castilleae (Moraceae). Their sister group relationship would not be recognised until 26 years later (Datwyler \& Weiblen, 2004). Contrary to Corner's assertion, neither did Ficus originate in the "post-Jurassic Solomon Islands" nor does phylogenetic evidence 
support pachycauly as the ancestral condition. So, while his theory may have been wrong, as always, his observations were right on the mark.

Our work was further motivated by Corner's poetic statements like “... it is clear that the wasps have classified the figs better than the botanists" (1955) and "there is such a close interaction between all the fig-insects, the flowers, and the atmosphere inside the fig, that...no detail of construction or chemistry can be neglected" (1988: 527). His writings continue to serve as an invitation to the field and to observe with care. In our case, contemplating the fig wasps and unusual sexual systems of Ficus sect. Papuasyce led to the discovery of Ficus umbrae.

Monoecious species such as Ficus microdictya produce seeds and pollen while supporting pollinators in the same syconium. Species such as Ficus itoana bear syconia of two types on separate trees (Weiblen, 2000). These syconia are morphologically gynodioecious but functionally dioecious. Seed figs have pistillate florets and neutered staminate florets whereas gall figs have functional staminate florets and pistillate florets, the latter being galled by pollinators instead of producing seed. Interactions between variable style lengths and ovipositor lengths are known to mediate whether syconia are functionally male, female, or hermaphroditic (Weiblen, 2004). With monoecy as the ancestral condition of the genus and an apparent transition to functional dioecy in Ficus subgenus Sycomorus (Weiblen, 2000), Ficus microdictya in Ficus sect. Papuasyce represents a rare evolutionary reversal to the ancestral monoecious condition. Berg \& Corner (2005) reported uncharacteristic style length variation in Ficus itoana relative to other functionally dioecious species. Instead of short-styled florets in gall figs and long-styled florets in seed figs, they reported pistillate florets of both types in seedbearing and pollen-bearing figs. We observed the same in Ficus umbrae but unlike F. itoana, the gall figs produce seed in addition to pollen. Souto-Vilarós et al. (2018) erroneously described this condition as functional androdioecy but, as a matter of fact, Ficus umbrae is functionally gynomonoecious. This newly discovered sexual system possibly represents an intermediate step in the co-evolutionary dynamics of fig pollination and an invitation for future study.

In closing we suggest that the first author, a third-generation student of Corner, like the second author before him, and Mabberley before him, continue to demonstrate that much is yet to be learned from the lives of plants. More than 50 years after scientific reductionism threatened to extinguish the study of whole organisms, Corner (1963) wrote, "...I have been rent... by two forces which would make of me a student of the microcosm of protoplasm and a disciple of its greatness. They are the forces splitting biology into macromolecules and macro-organisms, and I do not know how this rift may be spanned." and "The young botanist...models molecules and chromosomes, and works very largely in vitro". We think he was prescient in offering hope that "Nevertheless, if biology is not to stand still, the pendulum will return and its amplitude will be the strength of those who have put their trust in the macrocosm". Recognising that the multi-generational pendulum has indeed swung in favour of natural history, we dedicate our work to E.J.H. Corner and his student, D.J. Mabberley. 
ACKNOWLEDGEMENTS. The authors thank the staff of the New Guinea Binatang Research Centre for field assistance, customary landowners for access to field sites on tribal lands. We also thank staff at the herbaria of CANB, MPU, and SING for providing high-resolution scans and photos of material, Jérôme Munzinger (MPU) for providing field photos and material for Ficus hystricicarpa, Linda M. Lufkin for illustrating F. hystricicarpa, and Marilyn Garber illustrating F. umbrae. This work was supported by the National Science Foundation under grants DEB 0211591, DEB 0515678 and DEB 0841885 as well as the Grant Agency of the Czech Republic grant number 15-24571S. Fieldwork and specimen export was conducted with permission of the PNG Forest Research Institute and PNG National Research Institute.

\section{References}

Berg, C.C. \& Corner, E.J.H. (2005). Moraceae. Flora Malesiana, ser. 1, Seed Plants, vol. 17. Leiden: Naturalis Biodiversity Center.

Clement, W.L. \& Weiblen, G.D. (2009). Morphological evolution in the mulberry family (Moraceae). Syst. Bot. 34: 530-552.

Corner, E.J.H. (1955). Revision of Ficus. Fl. Males. Bull. 11: 428-430.

Corner, E.J.H. (1958). An Introduction to the distribution of Ficus. Reinwardtia 4(3): 325-355.

Corner, E.J.H. (1960). Taxonomic notes on Ficus Linn., Asia and Australasia. I. Subgen.

Urostigma (Gasp.) Miq. II. Subgen. Pharmacosycea Miq. III. Subgen. Ficus and sect. Ficus. IV. Subgen. Ficus sect. Sycidium Miq. Gard. Bull. Sing. 17(3): 368-485.

Corner, E.J.H. (1963). Why Ficus, why Moraceae? Fl. Males. Bull. 18: 1000-1004.

Corner, E.J.H. (1978). Ficus dammaropsis and the multibracteate species of Ficus sect. Sycocarpus. Philos. Trans., Ser. B 281: 373-406.

Corner, E.J.H. (1988). Wayside trees of Malaya, ed. 3. Kuala Lumpur: Malayan Nature Society.

Cruaud, A., Rønsted, N., Chantarasuwan, B., Chou, L.S., Clement, W.L., Couloux, A., Cousins, B., Genson, G., Harrison, R.D., Hanson, P.E. et al. (2012). An extreme case of plantinsect codiversification: figs and fig-pollinating wasps. Syst. Biol. 61(6): 1029-1047.

Datwyler, S.L. \& Weiblen, G.D. (2004). On the origin of the fig: phylogenetic relationships of Moraceae from $n d h F$ sequences. Amer. J. Bot. 91: 767-777.

Mack, A. L. \& Wright, D.D. (1996). Notes on the occurrence and feeding of birds at Crater Mountain Biological Research Station, Papua New Guinea. Emu 96: 89-101.

Moe, A.M., Clement, W.L. \& Weiblen, G.D. (2012). Rapid evolution of pollinator-mediated plant reproductive isolation. In: R.S. Singh, J. Xu \& R.J. Kulathinal (eds) Evolution in the fast lane: Rapidly evolving genes and genetic systems, pp. 266-273. Oxford: Oxford University Press.

Moe, A.M. \& Weiblen, G.D. (2010). Molecular divergence in allopatric Ceratosolen pollinators (Agaonidae) of geographically widespread Ficus (Moraceae) species. Ann. Entomol. Soc. Am. 103: 1025-1037.

Moe, A.M. \& Weiblen, G.D. (2012). Pollinator-mediated reproductive isolation among dioecious fig species (Ficus, Moraceae). Evolution 66: 3710-3721.

Novotny, V. et al. [16 authors] (2007). Low beta diversity of herbivorous insects in tropical forests. Nature 448: 692-695.

POWO (2019). Plants of the World Online. Facilitated by the Royal Botanic Gardens, Kew. Published on the Internet. http://www.plantsoftheworldonline.org. Accessed11 June 2019. 
Rønsted, N., Weiblen, G.D., Savolainen, V. \& Cook, J.M. (2008). Phylogeny, biogeography, and ecology of Ficus section Malvanthera (Moraceae). Molec. Phylogenet. Evol. 48(1): $12-22$.

Schneider, C.A., Rasband, W.S. \& Eliceiri, K.W. (2012). NIH Image to ImageJ: 25 years of image analysis. Nature Methods 9(7): 671-675.

Shanahan, M., So, S., Compton, G. \& Corlett, R. (2001). Fig-eating by vertebrate frugivores: a global review. Biol. Rev. 76: 529-572.

Souto-Vilarós, D., Proffit, M., Buatois, B., Rindos, M., Sisol, M., Kuyaiva, T., Isua, B., Michalek, J., Darwell, C.T., Hossaert-McKey, M. et al. (2018). Pollination along an elevational gradient mediated both by floral scent and pollinator compatibility in the fig and fig-wasp mutualism. J. Ecol. 106: 2256-2273.

Van Achterberg, C. \& Weiblen, G.D. (2000). Ficobracon brusi gen. nov. \& spec. nov. (Hymenoptera: Braconidae), a parasitoid reared from figs in Papua New Guinea. Zool. Meded. 74: 51-55.

Van Steenis-Kruseman, M.J. \& Van Steenis, C.G.G.J. (1950). Malaysian plant collectors and collections. Flora Malesiana, ser. 1, Seed Plants, vol. 17. Leiden: Naturalis Biodiversity Center.

Vincent, J.B., Turner, B.L., Alok, C., Novotny, V., Weiblen, G.D. \& Whitfeld, T.J.S. (2018). Tropical forest dynamics in unstable terrain: a case study from New Guinea. J. Trop. Ecol. 34(3): 157-175.

Weiblen, G.D. (2000). Phylogenetic relationships of functionally dioecious Ficus (Moraceae) based on ribosomal DNA sequences and morphology. Amer. J. Bot. 87: 1342-1357.

Weiblen, G.D. (2004). Correlated evolution in fig pollination. Syst. Biol. 53(1): 128-139.

Weiblen, G.D. (2006). Moraceae of Papua. In: A.J. Marshall \& B.M. Beehler (eds) The ecology of Papua, pp. 404-407. Singapore: Periplus Editions.

Weiblen, G.D., Lomascolo, S.B., Oono, R. \& Dumont, E.R. (2010). Nutritional dimorphism in New Guinea dioecious figs. Biotropica 42(6): 656-663.

Weiblen, G.D., Yu, D.W. \& West, S.A. (2001). Pollination and parasitism in functionally dioecious figs. Proc. R. Soc. Lond. Biol. (268): 651-659.

Wiebes, J. T. (1963). Taxonomy and host preferences of Indo-Australian fig wasps of the genus Ceratosolen (Agaonidae). Tijdschr. Entomol. 106: 1-112.

Whitfeld, T.J.S. \& Weiblen, G.D. (2010). Five new Ficus species (Moraceae) from Melanesia. Harvard Pap. Bot. 15(1): 1-10. 